\title{
Different Nutrition and Supplementation Strategies and Health: Critical Remarks
}

\author{
Wojciech J Cynarski* \\ University of Rzeszow, Poland
}

*Corresponding author: Wojciech J Cynarski, University of Rzeszow, Rzeszow, Poland

Keywords: Nutrition; movement; health; martial arts

\section{Short Communication}

It's about nutrition and supplementation of physically active people (practicing martial arts). The author expresses his rather critical position regarding the strategy in this respect. Is proper nutrition so important for health and psychophysical fitness? Further dietary modifications and indications are to ensure the optimisation of nutrition. Meanwhile, the author claims that the main determinants are movement and regular physical exertion. Diet type and supplementation are of secondary importance. The author's own interests in nutrition, physical movement and health, as well as observations in this area began with a series of interesting conferences at the Poznań University of Physical Education in 2000 cf Cynarski [1]. The author's hypothesis was born even in his student years, when he practiced one of the martial arts himself. Solid training was not accompanied by any special efforts to choose a diet or special supplementation. The author's own 20-year observation (years 2000-2019) of two martial arts masters leads to similar observations confirming the hypothesis given above. Two cousins, i.e. genetically close people, were analyzed. Both have reached the master level of hanshi $\left(9^{\text {th }}\right.$ or $10^{\text {th }} \mathrm{dan}$ ) in various Japanese martial arts. With the fact that one of them still uses a meat-fat diet, avoiding carbohydrates. The second one - nutrition and supplementation according to the IPA method Cynarski, Sieber [2]. The latter Hanshi conducted an experiment in 2000. One of his students asked for help to lose a few kilos of body fat. Hanshi recommended him running and cycling after using a preparation available at the time in grocery stores and pharmacies (without a prescription), containing caffeine and L-carnitine. The student, however, used only isotonic drinks (electrolytes) and after a few weeks he obtained the effect. This effect proved to be permanent. This student is practicing today and already has a high degree $-5^{\text {th }}$ dan. It also maintains a slim figure. Just like both Hanshi. Many recommended nutrition and supplementation strategies are contradictory. For example, the Ukrainian scientist
Prof. Bolotov [3] is based on Ukrainian folk medicine and herbal medicine. However, his theses are often contradictory to nutrition recommendations, e.g. in prophylaxis and oncological treatment cf. Colbert [4]. In turn, mass culture has many natural or alternative dietary recommendations [5]. Isn't it just that you need to supply your body with all the ingredients and energy it needs? Is it not enough just a minimum of rationality, especially moderation in everything? An individual nutrition strategy only needs to be corrected if it leads to homeostasis disorders in the body. The living organism has a natural self-regulating ability. In the case of training in competitive sports, an adequate amount of basic ingredients and energy should be provided [Nurchis [6]; Park et al. [7]]. In turn, if you want to reduce your weight, your overall energy balance should be negative. In any case, however, for consumed products to build positive health potential, regular physical effort, properly dosed, is crucial [8]. This positive potential for health is co-created by the level of body efficiency, physical fitness (motor skills), the state of hardening, as well as the level of tolerance to various nutritional strategies.

\section{References}

1. Cynarski WJ (2000a) Żywienie - Ruch - Zdrowie. Sprawozdanie z Ogólnopolskiej Konferencji Naukowej - Zajączkowo, 25-27 maja 2000 [Nutrition - Movement - Health. Report on the $1^{\text {st }}$ National Scientific Conference - Zajaczkowo, 25-27 May 2000]," Scientific Review of IWFiZ WSP in Rzeszow" 4(1-2): 133-136.

2. Cynarski WJ, Sieber L (2015) Martial arts (alternative) medicine channel of transmission to Europe, "Ido Movement for Culture. Journal of Martial Arts Anthropology", 15(3): 8-21.

3. Bołotow B (2018) Zdrowie człowieka w niezdrowym świecie [Human health in an unhealthy world], EnsoPublishing, Warsaw [in Polish].

4. Colbert D (2010) Biblia leczy Rak Metoda oparta na zbilansowanej diecie [The Bible heals Cancer A method based on a balanced diet], M Wydawnictwo, Kraków [in Polish]. 
5. Cynarski WJ (2018) Physical movement and healing in alternative medicine: in perspective of sociology of leisure and mass culture [in:] Baić $\mathrm{M}$ et al. [eds.], 14 ${ }^{\text {th }}$ International Scientific Conference of Sport Kinetics 2018 -Movement in Human Life and Health, Porec Croatia pp.142-148.

6. Nurchis R (2002) Nutrition and the role of Diet in Martial Arts Competition. Journal of Asian Martial Arts 11(1): 28-51.
7. Park S, Alencar M, Sassone J, Madrigal L, Ede A (2019) Self-reported methods of weight cutting in professional mixed-martial artists: how much are they losing and who is advising them. Journal of the International Society of Sports Nutrition 16(52).

8. Cynarski WJ (2000b) Zdrowie a żywienie i ruch - refleksje pokonferencyjne [Health and nutrition and movement - post-conference reflections] Ido Movement for Culture 1: 142-145.
(C) $\left(\begin{array}{l}\text { This work is licensed under Creative } \\ \text { Commons Attribution } 4.0 \text { License }\end{array}\right.$

To Submit Your Article Click Here:

Submit Article

DOI: 10.32474/RRHOAJ.2019.04.000191

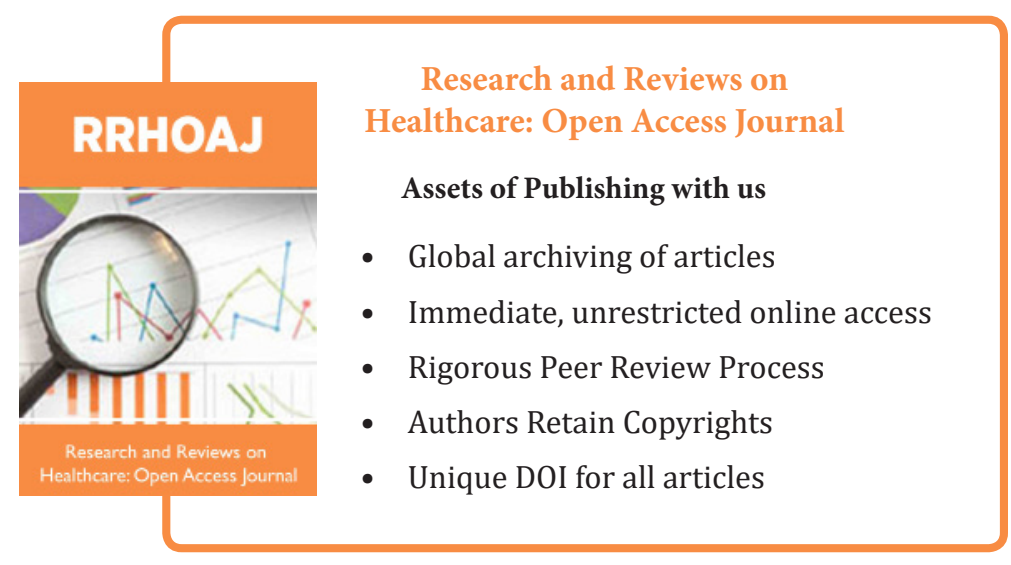

